\title{
Comparison of mercury concentrations measured at several sites in the Southern Hemisphere
}

\author{
F. Slemr ${ }^{1}$, H. Angot ${ }^{2}$, A. Dommergue ${ }^{2,3}$, O. Magand $^{3}$, M. Barret ${ }^{2,3}$, A. Weigelt $^{4}$, R. Ebinghaus ${ }^{4}$, E.-G. Brunke ${ }^{5}$,

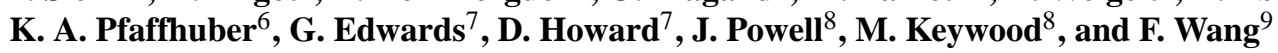 \\ ${ }^{1}$ Max-Planck-Institute for Chemistry, Hahn-Meitner-Weg 1, 55128 Mainz, Germany \\ ${ }^{2}$ Université Grenoble Alpes, LGGE, 38041 Grenoble, France \\ ${ }^{3}$ CNRS, LGGE, 38041 Grenoble, France \\ ${ }^{4}$ Helmholtz-Zentrum Geesthacht (HZG), Institute of Coastal Research, Max-Planck-Strasse 1, \\ 21502 Geesthacht, Germany \\ ${ }^{5}$ South African Weather Service c/o CSIR, P.O. Box 320, Stellenbosch 7599, South Africa \\ ${ }^{6}$ Norwegian Institute for Air Research (NILU), P.O. Box 100, 2027 Kjeller, Norway \\ ${ }^{7}$ Macquarie University, Environmental Science, Sydney, NSW, Australia \\ ${ }^{8}$ CSIRO Ocean and Atmosphere Flagship Research, Aspendale, VIC, Australia \\ ${ }^{9}$ Centre for Earth Observation Science, Department of Environment and Geography, \\ University of Manitoba, Winnipeg, MB, R3T 2N2, Canada
}

Correspondence to: F. Slemr (franz.slemr@mpic.de)

Received: 6 October 2014 - Published in Atmos. Chem. Phys. Discuss.: 3 December 2014

Revised: 7 February 2015 - Accepted: 25 February 2015 - Published: 19 March 2015

\begin{abstract}
Our knowledge of the distribution of mercury concentrations in air of the Southern Hemisphere was until recently based mostly on intermittent measurements made during ship cruises. In the last few years continuous mercury monitoring has commenced at several sites in the Southern Hemisphere, providing new and more refined information. In this paper we compare mercury measurements at several remote sites in the Southern Hemisphere made over a period of at least 1 year at each location. Averages of monthly medians show similar although small seasonal variations at both Cape Point and Amsterdam Island. A pronounced seasonal variation at Troll research station in Antarctica is due to frequent mercury depletion events in the austral spring. Due to large scatter and large standard deviations of monthly average median mercury concentrations at Cape Grim, no systematic seasonal variation could be found there. Nevertheless, the annual average mercury concentrations at all sites during the 2007-2013 period varied only between 0.85 and $1.05 \mathrm{ng} \mathrm{m}^{-3}$. Part of this variability is likely due to systematic measurement uncertainties which we propose can be further reduced by improved calibration procedures. We conclude that mercury is much more uniformly distributed throughout
\end{abstract}

the Southern Hemisphere than the distributions suggested by measurements made onboard ships. This finding implies that smaller trends can be detected in shorter time periods. We also report a change in the trend sign at Cape Point from decreasing mercury concentrations in 1996-2004 to increasing concentrations since 2007.

\section{Introduction}

Our knowledge of the distribution of mercury in air over the Southern Hemisphere is mostly based on measurements made during ship cruises. According to the most comprehensive review of shipboard measurements made between 1990 and 2009 by Soerensen et al. (2012) mercury concentrations varied between $0.72 \mathrm{ng} \mathrm{m}^{-3}$ reported by Kuss et al. (2011) for the southern Atlantic Ocean and $2.20 \mathrm{ng} \mathrm{m}^{-3}$ observed by Xia et al. (2010) over the southeastern Indian Ocean. These data were collected in different areas during different seasons, typically over a period of 1 or 2 months. Only a few of these measurements were accompanied by measurements of tracers specific to anthropogenic pollution 
and the influence from the ship such as $\mathrm{CO}$, nitrogen oxides, and particles. Consequently, the influence of sources such as from biomass burning, regional pollution, and pollution from the ship itself could not be properly filtered out from the data. Part of the reported variability may also be due to the use of frequently undeclared and non-uniform standard conditions under which these concentrations are reported. Mercury concentrations in $\mathrm{ng} \mathrm{m}^{-3}$ are usually reported at a standard pressure of $1013 \mathrm{hPa}$ and a standard temperature of $273.14 \mathrm{~K}$. However, some researchers and organisations use $293.14 \mathrm{~K}$ or $298.14 \mathrm{~K}$. Since the same concentrations reported at 273.14 and $298.14 \mathrm{~K}$ differ by almost $10 \%$, the non-uniform standard conditions alone would prevent the detection of the statistically significant decrease in annual median mercury concentrations at Cape Point from $\sim 1.3 \mathrm{ng} \mathrm{m}^{-3}$ in 1996 to below $1.2 \mathrm{ng} \mathrm{m}^{-3}$ in 2004 (Slemr et al., 2008). Lastly, averages and standard deviations are quite frequently quoted without the number of measurements on which they are based. This means that the averages or medians cannot be weighed by the number of the measurements. It also makes statistical tests for the differences of averages impossible. It is not surprising that, using such data, Soerensen et al. (2012) concluded that no significant trend in the Southern Hemisphere could be detected so far. While we agree with this conclusion, a qualification is required: the quality of the data used by Soerensen et al. (2012) does not allow detection of trends smaller than their variability, i.e. some $50 \%$ or even more. Consequently, with trends of up to $\sim 2 \%$ per year (Slemr et al., 2008; Ebinghaus et al., 2011), it would take several decades to detect trends from measurements onboard ships.

Recently, mercury has been measured continuously at several remote sites in the Southern Hemisphere over periods of a year or more. In this paper we will compare these measurements in terms of their monthly and annual statistics. We selected stations which are either baseline stations (Amsterdam Island, Troll research station in Antarctica) or where additional measurements (e.g. CO, ${ }^{222} \mathrm{Rn}$, wind direction, aerosol) allow us to filter out baseline conditions (Cape Point and Cape Grim). The results show that atmospheric mercury is more uniformly distributed over the Southern Hemisphere than the measurements onboard ships suggest. Stationary sites with continuous and reproducible measurements of higher quality over longer periods allow for the detection of smaller trends in shorter time periods.

\section{Experimental}

Figure 1 shows the location of the sites whose data are used in this paper: Amsterdam Island, Cape Grim, Cape Point, Troll research station, and Galápagos Archipelago.

The Cape Point site (CPT, $34^{\circ} 21^{\prime} \mathrm{S}, 18^{\circ} 29^{\prime} \mathrm{E}$ ) is operated as one of the Global Atmospheric Watch (GAW) baseline monitoring observatories of the World Meteorological Orga-

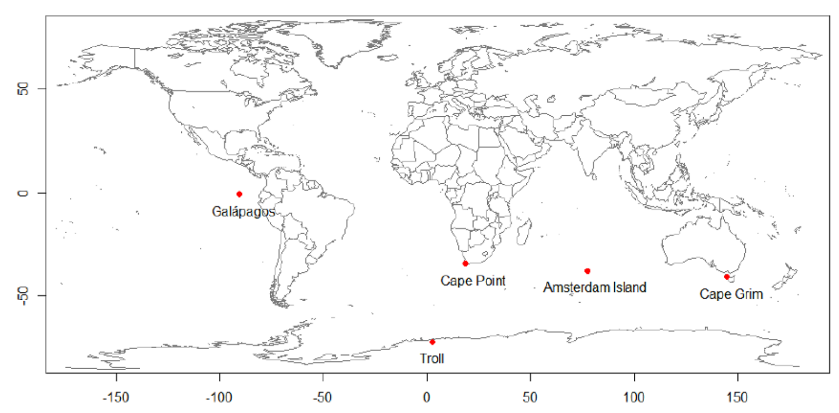

Figure 1. The location of the sites whose data are reported in this paper.

nization (WMO). The station is located on the southern tip of the Cape Peninsula within the Cape Point National Park on top of a peak $230 \mathrm{~m}$ a.s.l. and about $60 \mathrm{~km}$ south of Cape Town. The station has been in operation since the end of the 1970s and its current continuous measurement portfolio includes $\mathrm{Hg}, \mathrm{CO}, \mathrm{O}_{3}, \mathrm{CH}_{4}, \mathrm{~N}_{2} \mathrm{O},{ }^{222} \mathrm{Rn}, \mathrm{CO}_{2}$, several halocarbons, particles, and meteorological parameters. The station receives clean marine air masses for most of the time. Occasional events with continental and polluted air can easily be filtered out using a combination of the $\mathrm{CO}$ and ${ }^{222} \mathrm{Rn}$ measurements (Brunke et al., 2004). Gaseous elemental mercury (GEM) was measured by a manual amalgamation technique (Slemr et al., 2008) between September 1995 and December 2004 and has been measured by the automated Tekran 2537B instrument (Tekran Inc., Toronto, Canada) since March 2007. Only the Tekran data are reported here. These data were obtained in compliance with the standard operating procedures of the GMOS (Global Mercury Observation System, www.gmos.eu) project. The instrument has been run with a 15 min sampling frequency. For data analysis, 30 min averages were used. On average, $30 \%$ of the data were classified as baseline using the ${ }^{222} \mathrm{Rn} \leq 250 \mathrm{mBq} \mathrm{m}^{-3}$ criterion.

Amsterdam Island (AMS, $37^{\circ} 48^{\prime} \mathrm{S}, 77^{\circ} 33^{\prime} \mathrm{E}$ ) is a small isolated island $\left(55 \mathrm{~km}^{2}\right)$ located in the Indian Ocean $3400 \mathrm{~km}$ east of Madagascar. AMS is a GAW global station established in 1967. The climate of Amsterdam Island is mild oceanic, with frequent presence of clouds. Measurements are performed at Pointe Bénédicte station, which is located $2 \mathrm{~km}$ west of the Saint Martin de Viviès base on the edge of a cliff $55 \mathrm{~m}$ a.s.l. (GPS coordinates: $37^{\circ} 48^{\prime} \mathrm{S}, 77^{\circ} 33^{\prime} \mathrm{E}$ ). GEM has been measured using a Tekran 2537B connected to a Tekran 1130/1135 speciation unit since January 2012 with a 5 min sampling frequency. For data analysis, $1 \mathrm{~h}$ averages were used. Details on operation and calibration procedures are given in Angot et al. (2014) and follow GMOS standard operating procedures. The station receives clean marine air masses almost all the time.

The Norwegian Antarctic Troll research station (TRS) is located in Queen Maud Land at $72^{\circ} 01^{\prime} \mathrm{S}$ and $2^{\circ} 32^{\prime} \mathrm{E}$ at an elevation of $1275 \mathrm{~m}$ and about $220 \mathrm{~km}$ from the Antarctic coast. 


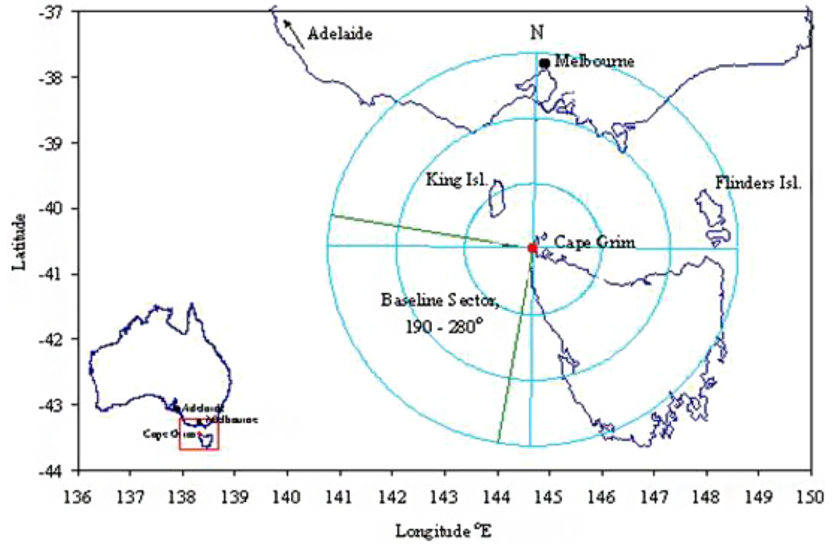

Figure 2. Location of the Cape Grim station and definition of the baseline sector.

The station has been in operation since January/February 2007 and its current continuous measurements include mercury, $\mathrm{CO}, \mathrm{O}_{3}$, particles, greenhouse gases, hydrocarbons, persistent organic compounds (POPs) and meteorological parameters (Hansen et al., 2009; Pfaffhuber et al., 2012). Mercury has been measured using the Tekran 2537B instrument since February 2007 with a 5 min sampling frequency. For data analysis, $1 \mathrm{~h}$ averages were used. The original mercury concentrations were reported at a standard temperature of $293.14 \mathrm{~K}$ and were converted to the standard temperature of $273.14 \mathrm{~K}$ to be comparable with all other data reported here.

The Cape Grim Baseline Air Pollution Station is located on the north-western coast of Tasmania, Australia $\left(40^{\circ} 41^{\prime} \mathrm{S}\right.$, $144^{\circ} 41^{\prime}$ E, Fig. 2). The Cape Grim Baseline Air Pollution Station was established in 1976 to monitor and study global atmospheric composition and is part of the WMO GAW programme. Measurements at Cape Grim include greenhouse gases such as $\mathrm{CO}_{2}, \mathrm{CH}_{4}, \mathrm{~N}_{2} \mathrm{O}, \mathrm{O}_{3}$, reactive nitrogen oxides, stratospheric ozone depleting chemicals such as chlorofluorocarbons (CFCs), radon, and GEM. The Tekran 2537A instrument was run with $5 \mathrm{~min}$ sampling time. For data analysis, $15 \mathrm{~min}$ averages were used. Additionally, meteorological parameters are measured, such as wind speed and direction, rainfall, temperature, humidity, air pressure, solar radiation, along with condensation nuclei $(\mathrm{CN})$ concentration (particles greater than $10 \mathrm{~nm}$ ), ultrafine condensation nuclei concentration (greater than $3 \mathrm{~nm}$ ), aerosol absorption, aerosol scattering, cloud condensation nuclei concentration and rainfall chemical composition. Baseline conditions are defined as those with wind directions at $50 \mathrm{~m}$ altitude lying between 190 and $280^{\circ}$. In addition, $\mathrm{CN}$ should be less than a threshold concentration determined from 5 years of $\mathrm{CN}$ data for the current month based on the 90th percentile of $\mathrm{CN}$ hourly medians for this period, interpolated using cubic splines to give daily values (Fig. 2). During 2011-2013, the station received baseline marine air for $33 \%$ of the time.
All mercury measurements reported here were made by an automated dual channel, single amalgamation, cold vapour atomic fluorescence analyser (Tekran-Analyzer model 2537 A or B, Tekran Inc., Toronto, Canada). The instrument features two gold cartridges. While one is adsorbing mercury during a sampling period, the other is being thermally desorbed using argon as a carrier gas. Mercury is detected using cold vapour atomic fluorescence spectroscopy (CVAFS). The functions of the cartridges are then interchanged, allowing continuous sampling of the incoming air stream. The instrument can be combined with a speciation unit (Tekran 1130/1135) consisting of a denuder, aerosol filter and pyrolyser that enables a determination of GEM, gaseous oxidised mercury $(\mathrm{GOM})$, and particle-bound mercury (PM, $<2.5 \mu \mathrm{m})$ typically every $2-3 \mathrm{~h}$ (Landis et al., 2002). Operation and calibration of the instruments follow established and standardised procedures (e.g. Steffen and Schroeder, 1999). All mercury concentrations reported here are given in $\mathrm{ng} \mathrm{m}^{-3}$ at $273.14 \mathrm{~K}$ and $1013 \mathrm{hPa}$.

In this paper we compare measurements at different sites in terms of monthly and annual average and median concentrations. Random uncertainties of individual measurements will average out and all we have to discuss are thus the systematic uncertainties, i.e. biases. The Tekran analyser is a complex instrument and the systematic uncertainties of its measurements depend on the operation procedure, the performance of the instrument, and the experience of its operators. All instruments used in this study are equipped with an internal mercury permeation source that is used to check and adjust periodically the instrument span and zero, typically every $25-72 \mathrm{~h}$ depending on the standard operating procedures that are used. This periodical internal calibration removes drifts both in span and zero that are caused mostly by the temperature and ageing of the fluorimeter lamp. The permeation rate of $\sim 1 \mathrm{pg} \mathrm{Hg} \mathrm{s}^{-1}$ is, however, too low to allow a gravimetric determination of the permeation rate within a reasonable time period, as is usually done when certifying permeation devices for other gases (Barratt, 1981). Consequently, the permeation rate is calibrated every 6-12 months by repeated injection (at least 10 injections) of known volumes of gas saturated with mercury vapour at a known temperature. A skilled operator can achieve an individual injection precision of $\sim 3 \%$, resulting in an uncertainty of $\sim 1 \%$ for 10 injections. The flow rate uncertainty of $\sim 1 \%$ represents the second major contribution to the overall systematic uncertainty (Widmer et al., 1982). Adding smaller contributions from uncertainties associated with the injected volume and the temperature of the mercury vapour saturating device yields an overall systematic uncertainty of $\sim 3 \%$. We consider this to be the lower limit of the overall systematic uncertainty because this estimate assumes ideal performances of the instrument, its internal permeation device, the calibration mercury vapour saturating device, the injection syringes, as well as of the instrument operators. 
A comprehensive analysis of all random and systematic uncertainties involved in a single manual determination of mercury concentration in air is given by Brown et al. (2008), who estimated the combined relative uncertainty to be $16.7 \%$ at the concentration of $1.2 \mathrm{ng} \mathrm{m}^{-3}$. This uncertainty includes the uncertainty from different published mercury vapour pressure curves and can be reduced to $12.6 \%$ when one vapour pressure curve is accepted to be correct, as is the case here. This uncertainty analysis, however, is not directly applicable to measurements with the Tekran instrument because most items in the uncertainty budget are random rather than systematic. The combined systematic uncertainty (square root of the sum of uncertainties in quadrature) from uncertainties in flow calibration (2\%) and detector calibration $(7 \%)$ would be $\sim 7 \%$. Since one vapour pressure curve was used, the $5.5 \%$ uncertainty in the saturated mercury concentration can be neglected. The overall systematic uncertainty would then be $\sim 3 \%$ and is comparable to our estimate.

Contributions of deviations from an ideal performance, such as slow deactivation of the traps, difference between the concentrations from the two traps, contamination of the switching valves and traps, and leaks (Steffen et al., 2012), are difficult to quantify. Thus we take published results of Tekran instrument intercomparisons as a measure of practically achievable systematic uncertainty. In an intercomparison described by Ebinghaus et al. (1999) three Tekran instruments that were operated side by side at Mace Head were biased by $0.02-0.11 \mathrm{ng} \mathrm{m}^{-3}$ (median $0.01-$ $0.13 \mathrm{ng} \mathrm{m}^{-3}$ ) against each other. With an average concentration of $1.75 \mathrm{ng} \mathrm{m}^{-3}$, this represents the highest systematic uncertainty of $\sim 6 \%$. Two Tekran instruments were run side by side for 4 days at a site in Tuscany in June 1998 (Munthe et al., 2001) with an average bias of $9 \%$. Mercury was measured by five Tekran instruments for 28 days within a 6-week period in May and June 2006 at German EMEP station Waldhof (Aas et al., 2006). The median concentrations were $2.02,1.88,1.77,1.70$, and $1.69 \mathrm{ng} \mathrm{m}^{-3}$, and their average was $1.81 \pm 0.14 \mathrm{ng} \mathrm{m}^{-3}$. The average bias was thus $\sim 8 \%$ and the bias between the instruments with the lowest and highest readings was $\sim 18 \%$ (related to the average concentrations). In summary, based on experimental evidence, we can expect an average systematic uncertainty of $\sim 10 \%$, in extreme cases up to $20 \%$.

Despite using the same instrumentation, the measurements may target different mercury species at different sites, depending on their configuration and/or local conditions. At Amsterdam Island the instrument was operated with the Tekran 1130/1135 speciation unit. It showed GOM concentrations of less than $5 \mathrm{pg} \mathrm{m}^{-3}$ representing less than $1 \%$ of the total gaseous mercury (TGM) concentrations of $\sim 1 \mathrm{ng} \mathrm{m}^{-3}$ (Angot et al., 2014). The data for Amsterdam Island presented here are stated explicitly as GEM. The instruments at Cape Point, Cape Grim, and Troll research station are operated without speciation units but with PTFE
(Teflon) filters to protect the instrument from sea salt and other particles. Although not proven, we assume that the surface active GOM in the humid air of the marine boundary layer at Cape Point and Cape Grim will be filtered out together with PM, partly by the salt particle loaded PTFE filter (denuders coated with $\mathrm{KCl}$ are used to adsorb GOM (Landis et al., 2002)) and partly on the walls of the inlet tubing. Consequently, we assume that measurements at Cape Point and Cape Grim represent GEM only and are thus directly comparable to those at Amsterdam Island. Although at Troll research station the same configuration with a PTFE filter is used, measurements by Temme et al. (2003) showed that at the low temperature and humidity prevailing at this site, GOM passed the inlet tubing and the PTFE filter. The measurements at Troll research station are thus assumed to represent TGM. As the GOM concentrations at Amsterdam Island in particular and in the marine boundary layer in general are below $10 \mathrm{pg} \mathrm{m}^{-3}$ (Soerensen et al., 2010; Angot et al., 2014), the difference between TGM and GEM at Amsterdam Island, Cape Grim and Cape Point is usually less than $1 \%$, which is insignificant when compared with the uncertainties discussed above. Consequently, GEM measurements at Cape Point, Cape Grim and Amsterdam Island are comparable to TGM measured at Troll research station. We caution, however, that recent studies have shown that the $\mathrm{KCl}$-coated denuder in the Tekran speciation technique does not efficiently collect all GOM (Gustin et al., 2013; Huang et al., 2013; Ambrose et al., 2013). The bias between the TGM measurements at Troll research station and GEM measurements at all other stations can thus be larger.

The pair data difference tests were done using a $t$ test (Kaiser and Gottschalk, 1972). A Mann-Kendal test for trend detection and the estimate of Sen's slope were made using the program by Salmi et al. (2002).

\section{Results and discussion}

\subsection{Comparison of seasonal variations}

Figure 3 shows seasonal variation of median mercury concentrations at Amsterdam Island, Cape Point, Cape Grim, and Troll research station in Antarctica during 2011-2013. Plotted are the averages of monthly median mercury concentrations and their standard deviations. We prefer here the use of monthly medians because they are less influenced by extreme values. The medians for Cape Point and Cape Grim were calculated both from unfiltered data and data filtered using the ${ }^{222} \mathrm{Rn} \leq 250 \mathrm{mBq} \mathrm{m}^{-3}$ criterion for Cape Point and the baseline criteria mentioned above for Cape Grim. Pair tests for systematic differences between the monthly medians of filtered and unfiltered data (Kaiser and Gottschalk, 1972) did not show any significant difference (significance level $<95 \%)$ at both sites. Thus pollution events occasionally observed at Cape Point (Brunke et al. 2012; Slemr et 


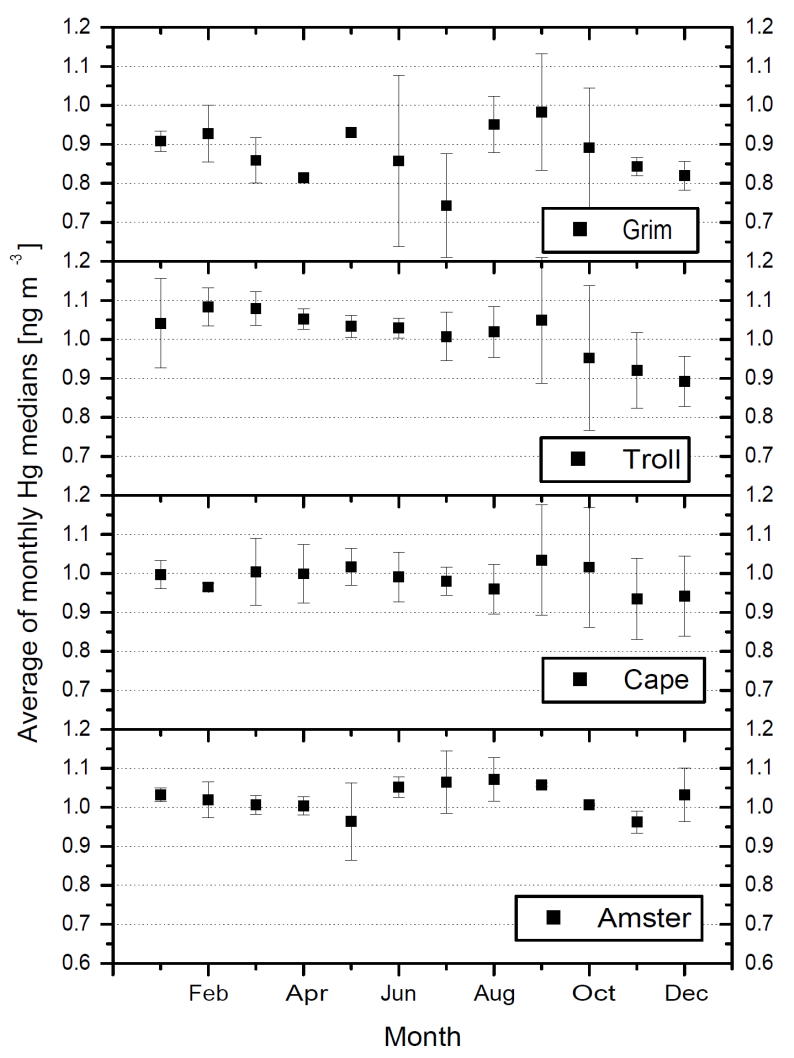

Figure 3. Seasonal variation of average monthly medians of mercury concentrations in 2011-2013 at Cape Point (no data in February 2011) and Troll research station (no data in September and October 2011). At Amsterdam Island the data cover only the 28 January 2012 to 31 December 2013 period and, at Cape Grim, data from January to August and November 2011, and April, May and October 2013 are missing. Bars denote the standard deviation of the monthly averages.

al., 2013) and at Cape Grim have no substantial influence on the monthly medians of mercury concentrations. This finding also has implications for the data from Amsterdam Island: if the influence of continental air masses is unimportant at Cape Point located on the coast of South Africa and at Cape Grim near the Australian continent, even less influence can be expected at Amsterdam Island, an isolated island in the middle of the Indian Ocean. Consequently, medians of unfiltered data from all sites were used when constructing this figure.

The smallest seasonal variation, within $\sim 0.1 \mathrm{ng} \mathrm{m}^{-3}$, is observed at Cape Point and Amsterdam Island, and the data which vary around $1 \mathrm{ng} \mathrm{m}^{-3}$ are very similar. In fact, a pair test for the differences in monthly medians ( 23 months) revealed no significant difference (significance level <95\%) between the measurements at Amsterdam Island and Cape Point. Standard deviations of monthly medians averaged over 3 years (2011-2013) at Cape Point tend to be somewhat larger than those averaged over 2 years at Amsterdam Island, possibly due to inter-annual variations. Taking the standard deviations into account, there is no seasonal variation discernible at both sites.

The seasonal variation at Troll research station is, at $\sim 0.2 \mathrm{ng} \mathrm{m}^{-3}$, substantially larger, whereas the monthly standard deviations are comparable to those at Cape Point. Minimum values are observed in October, November, and December, which are the months with frequent mercury depletion events in Antarctica (Temme et al., 2003; Pfaffhuber et al., 2012), and maximum values tend to occur in February and March and are, at $\sim 1.1 \mathrm{ng} \mathrm{m}^{-3}$, somewhat higher than at Cape Point and Amsterdam Island. In November and December the monthly average concentrations are, at $\sim 0.9 \mathrm{ng} \mathrm{m}^{-3}$, somewhat lower than at Cape Point and Amsterdam Island but comparable when averaged over the whole year (see Table 1). A pair test for differences in monthly medians at Cape Point, Amsterdam Island, and Troll research station revealed no statistically significant difference between them in the 2011-2013 period (33 months for Cape Point vs. Troll, 24 months for Amsterdam Island vs. Troll). There is a significant difference (>99\%, 79 months) between medians at Cape Point and Troll research station over the period 20072013, which might be due to different trends at both sites.

Cape Grim data show the largest seasonal variation of $\sim 0.25 \mathrm{ng} \mathrm{m}^{-3}$, the largest monthly standard deviations, and the lowest annual average concentration of $\sim 0.85 \mathrm{ng} \mathrm{m}^{-3}$ of all four sites, some $15 \%$ below the annual mean concentrations at all other sites. Large standard deviations in September and October coincide with similar variability at Troll research station and Cape Point. Large and random scatter of the monthly values in other months suggests that the data from Cape Grim are not as homogeneous as those from other sites. Pair tests for differences in monthly medians detected a highly significant systematic difference between data from Cape Point and Amsterdam Island on the one hand and those from Cape Grim on the other (Cape Point vs. Cape Grim: > 99.9\%, 23 months; Amsterdam Island vs. Cape Grim: > 99.9\%, 21 months). Without additional QA/QC effort we cannot find out how many of these differences between the data from Cape Grim and from the other three sites are due to regional differences and/or due to the systematic uncertainties discussed in the experimental section.

\subsection{Comparison of annual averages}

The annual averages and medians for the Amsterdam Island, Cape Point, Cape Grim, and Troll research stations are given in Table 1. The table also contains an average of monthly medians for March, April, May, June, and October 2011 for Galápagos Archipelago (Wang et al., 2014). Located just south of the Equator, Galápagos Archipelago may be influenced by northern hemispheric air, especially in January, when the intertropical convergence zone (ITCZ) is at its southernmost position (Wang et al., 2014). The band of mixed northern and southern hemispheric air at ITCZ in the 
Table 1. Comparison of annual average and median mercury concentrations at Amsterdam Island, Cape Point, Cape Grim, Troll research station, and Galápagos Archipelago. Hourly data were available for Amsterdam Island and Troll research station, half-hourly data for Cape Point, 5-15 min data for Cape Grim, and monthly averages for Galápagos Archipelago. All concentrations are given in ng $\mathrm{m}^{-3}$ at $273.14 \mathrm{~K}$ and $1013 \mathrm{hPa}$.

\begin{tabular}{|c|c|c|c|c|c|c|}
\hline \multirow[t]{2}{*}{ Site } & \multicolumn{2}{|c|}{2011} & \multicolumn{2}{|c|}{2012} & \multicolumn{2}{|c|}{2013} \\
\hline & $\begin{array}{l}\text { Average and } \\
\text { standard deviation }\end{array}$ & $\begin{array}{l}\text { Median, number } \\
\text { of measurements }\end{array}$ & $\begin{array}{l}\text { Average and } \\
\text { standard deviation }\end{array}$ & $\begin{array}{l}\text { Median, number } \\
\text { of measurements }\end{array}$ & $\begin{array}{l}\text { Average and } \\
\text { standard deviation }\end{array}$ & $\begin{array}{l}\text { Median, number } \\
\text { of measurements }\end{array}$ \\
\hline Cape Point & $0.923 \pm 0.106$ & $0.934,13918$ & $1.017 \pm 0.095$ & $1.018,15040$ & $1.052 \pm 0.160$ & $1.040,7809$ \\
\hline Amsterdam Island & No data & No data & $1.025 \pm 0.065^{\mathrm{a}}$ & $1.028,6164^{\mathrm{a}}$ & $1.028 \pm 0.096$ & $1.027,7410$ \\
\hline Cape Grim & $0.959 \pm 0.146^{\mathrm{b}}$ & $0.976,3692^{\mathrm{b}}$ & $0.872 \pm 0.130$ & $0.854,35097$ & $0.848 \pm 0.112^{\mathrm{c}}$ & $0.858,36310^{\mathrm{c}}$ \\
\hline Troll & $1.032 \pm 0.192$ & $1.061,5876$ & $1.052 \pm 0.160$ & $1.040,7809$ & $0.970 \pm 0.162$ & $1.000,8196$ \\
\hline Galápagos Archipelago & $1.054 \pm 0.087^{\mathrm{d}}$ & $1.041,5$ months ${ }^{\mathrm{d}, \mathrm{e}}$ & No data & No data & No data & No data \\
\hline
\end{tabular}

a Temporal coverage 28 January 2012-31 December 2012

b Only September, October and December covered by measurements.

c No data in April, May and October.

d Only March, April, May, June, and October data were considered; February eliminated because of ITCZ proximity.

e Average of monthly medians.

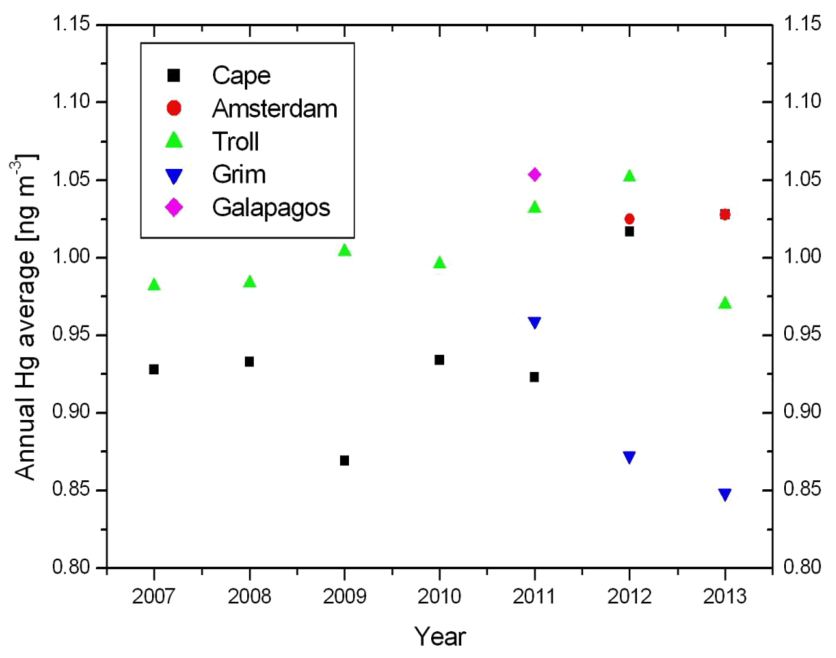

Figure 4. Annual average mercury concentrations at Cape Point, Amsterdam Island, Cape Grim, Troll research station and Galapagos Archipelago (Wang et al., 2014). Note that the 2013 annual averages at Cape Point and Amsterdam Island fall together.

marine boundary layer over the Atlantic Ocean tends to be quite narrow, usually less than $500 \mathrm{~km}$ broad (Slemr et al., 1985). If the same applies for the region around Galápagos Archipelago, then data from December, January and February could have been influenced by northern hemispheric air. Thus data for February 2011, although available, were not included.

Figure 4 shows an overview of the average mercury concentrations measured at different southern hemispheric sites during 2007-2013. It does not show the average mercury concentration of $1.32 \pm 0.23 \mathrm{ng} \mathrm{m}^{-3}$ measured at a coastal site in Suriname for the season when the ITCZ is located north of the site and air originates from the South Atlantic (Müller et al., 2012). As the ITCZ moves seasonally over the site in Suriname, the influence of northern hemispheric air is greater than at Galápagos Archipelago. Moreover, this site is also influenced by emissions from large-scale biomass burning in the Amazonas region (Ebinghaus et al., 2007; Müller et al, 2012). And last but not least, no annual statistics for southern hemispheric air can be made for Suriname because only seasonal concentrations are available. For these reasons, the measurements at Suriname are not included in further discussion.

Most of the annual medians and averages for individual sites in Table 1 differ by less than $0.02 \mathrm{ng} \mathrm{m}^{-3}$, implying that the data are nearly normally distributed. Only at the Troll research station do the differences between annual medians and averages tend to be larger, while the medians tend to exceed the averages (in 6 of the 7 years). This is probably due to the extremely low values during the depletion events which occur during the Antarctic spring.

The annual averages and medians at Amsterdam Island and Cape Point differ by 0.01 and $0.01 \mathrm{ng} \mathrm{m}^{-3}$, respectively, in 2012, and by 0.02 and $0.01 \mathrm{ng} \mathrm{m}^{-3}$, respectively, in 2013. When compared over the overlapping period in 2012 (28 January-31 December), the averages and medians at both sites differed merely by 0.00 and $0.01 \mathrm{ng} \mathrm{m}^{-3}$, respectively. The differences between Troll research station and the two other stations (Amsterdam Island and Cape Point) are substantially larger, by as much as 0.11 and $0.13 \mathrm{ng} \mathrm{m}^{-3}$ for 2011 averages and medians, respectively. In 2012 and 2013 the differences are below $0.1 \mathrm{ng} \mathrm{m}^{-3}$. Annual averages over the period of 2007-2013 show that the difference between Cape Point and Troll research station never exceeded $0.14 \mathrm{ng} \mathrm{m}^{-3}$, reached in 2009, and the average difference was $0.06 \mathrm{ng} \mathrm{m}^{-3}$. The highest difference in medians was $0.20 \mathrm{ng} \mathrm{m}^{-3}$, also in 2009 , and the average difference was $0.08 \mathrm{ng} \mathrm{m}^{-3}$.

Larger concentration differences are observed between Cape Grim and all other sites in 2011-2013. The annual 
averages and medians at Cape Grim were lower than at Amsterdam Island by 0.15 and $0.17 \mathrm{ng} \mathrm{m}^{-3}$, respectively, in 2012 , and by 0.18 and $0.17 \mathrm{ng} \mathrm{m}^{-3}$, respectively, in 2013. The differences in annual averages and medians at Cape Grim and Cape Point were somewhat lower in 2012 and somewhat higher in 2013 than the corresponding differences between Cape Grim and Amsterdam Island. In 2011, data for Cape Grim and Cape Point overlap only for the period from September 6 to October 19. In this period, the average and median concentrations at Cape Grim were, at $1.03 \pm 0.11(n=2328)$ and $1.04 \mathrm{ng} \mathrm{m}^{-3}$, respectively, substantially higher than $0.86 \pm 0.07(n=1474)$ and $0.86 \mathrm{ng} \mathrm{m}^{-3}$, respectively, at Cape Point.

Figure 4 shows that the annual average mercury concentrations at all sites vary within $\sim 0.2 \mathrm{ng} \mathrm{m}^{-3}$ from $0.85 \mathrm{ng} \mathrm{m}^{-3}$ (Cape Grim in 2013) to $\sim 1.05 \mathrm{ng} \mathrm{m}^{-3}$ (Galápagos Archipelago in 2011 and Troll research station in 2012). It is not clear how much of this variability is real or due to systematic uncertainty issues discussed in the experimental chapter. We believe that both components contribute and that the real variability of the annual average or median mercury concentrations at southern hemispheric sites not influenced by local and regional pollution is lower. Assuming a systematic uncertainty of $\sim 10 \%$ (see Experimental), the real variability at $1 \mathrm{ng} \mathrm{m}^{-3}$ in the Southern Hemisphere would be $\sim 0.1 \mathrm{ng} \mathrm{m}^{-3}$. This number can be viewed as a preliminary threshold for judging how representative the trends observed at any background site in the Southern Hemisphere are. With this threshold, much smaller trends at shorter time periods can be detected by long-term measurements at several sites when compared to shipboard measurements as reviewed by Soerensen et al. (2012).

\subsection{Trend at Cape Point}

Figure 4 shows an overall tendency of annual average mercury concentrations for Cape Point to increase with time. The Mann-Kendall test applied to annual averages and medians for 2007-2013 does not reveal a significant trend. However, when applied to monthly medians and averages, the trend is highly significant (at $99.99 \%$ significance level for averages and at $99.96 \%$ for medians). Senn's slope calculated from monthly averages is $0.018 \mathrm{ng} \mathrm{m}^{-3} \mathrm{yr}^{-1}$ (0.008-0.026 $\mathrm{ng} \mathrm{m}^{-3} \mathrm{yr}^{-1}$ at a significance level of $95 \%$ ) and, from monthly medians, $0.016 \mathrm{ng} \mathrm{m}^{-3} \mathrm{yr}^{-1}$ (0.007$0.025 \mathrm{ng} \mathrm{m}^{-3} \mathrm{yr}^{-1}$ ). This is the first analysis suggesting that mercury concentrations are increasing, as would be expected based on increasing worldwide anthropogenic emissions (Streets et al., 2009; Muntean et al., 2014). A decreasing trend of $-0.015 \mathrm{ng} \mathrm{m}^{-3} \mathrm{yr}^{-1}$ was derived from annual medians at Cape Point in the years 1996-2004 (Slemr et al., 2008), implying that the turning point was located between 2004 and 2007.

No trend could be detected in annual and monthly data from Troll research station over the same period: seven an- nual averages and medians are not sufficient for trend detection as they were for Cape Point, and the trend in monthly averages and medians is probably masked by the strong seasonal variation. All other southern hemispheric data sets are too short for any trend detection.

Over 7 years of measurements at Cape Point the concentrations had increased by $0.12 \mathrm{ng} \mathrm{m}^{-3}$ when calculated from the trend of the monthly averages and $0.11 \mathrm{ng} \mathrm{m}^{-3}$ from the trend of the monthly medians. The changing trend from a decrease during the 1996-2004 period to an increase during 2007-2013 at Cape Point is not the only sign that the hemispheric trends in mercury concentrations are changing. An analysis of 1996-2013 data from Mace Head, classified according to the geographical origin of the air masses, showed a) that the downward trend of mercury concentration in air masses originating from over the Atlantic Ocean south of $28^{\circ} \mathrm{N}$ is substantially lower than for all other classes originating north of $28^{\circ} \mathrm{N}$ and b) that all downward trends for air masses originating from north of $28^{\circ} \mathrm{N}$ are decelerating (Weigelt et al., 2015). The apparent inconsistency that no decelerating trend for air masses from south of $28^{\circ} \mathrm{N}$ was found can be explained by the fact that the changes of a smaller trend are likely to be more difficult to detect.

\section{Conclusions}

We compared mercury concentrations measured at Cape Point, Amsterdam Island, Cape Grim, and Troll research station in Antarctica. Amsterdam Island and Troll research station are background stations per se, and at Cape Point and Cape Grim the influence of local and regional pollution can be eliminated by using filters such as $\mathrm{CO}$ and ${ }^{222} \mathrm{Rn}$ or wind direction and aerosol concentrations. No systematic difference was found between the unfiltered and filtered monthly median mercury concentrations at Cape Point and Cape Grim. We find that in terms of annual averages and medians the gradients of background mercury concentrations within the Southern Hemisphere are small and do not exceed $0.2 \mathrm{ng} \mathrm{m}^{-3}$. Taking into account a systematic measurement uncertainty of $\sim 0.1 \mathrm{ng} \mathrm{m}^{-3}$, the real variability could be as low as $0.1 \mathrm{ng} \mathrm{m}^{-3}$. This is much lower than the variability of shipboard mercury measurements on which the discussions of secular trends of mercury concentrations have relied so far. Consequently, smaller trends at shorter time periods can be detected by increasingly available long-term measurements at background sites in the Southern Hemisphere. The preliminary threshold of $\sim 0.1 \mathrm{ng} \mathrm{m}^{-3}$ for trend detection will further decrease when the comparability of the data sets improves.

The discussion of the measurement uncertainties shows a large difference between a small theoretical uncertainty and the much larger uncertainty achieved experimentally during several intercomparisons. Sampling flow rate can be precisely calibrated, and thus we believe that most of the "sur- 
plus" uncertainty comes from the behaviour and calibration of the Tekran internal permeation source. The issues related to the injection of known amounts of mercury are relatively well known (for example, not all syringes and replacement needles are suitable) and the uncertainty caused by them can be reduced by meticulous work. To the best of our knowledge we could not find any information about the dynamical behaviour of the internal permeation source that would enable one to calculate how much time is needed to stabilise the permeation rate (Barratt, 1981). Working practice, however, suggests that the time needed to stabilise the permeation rate increases with the decreasing permeation rate. We surmise that the very small permeation rate of the device in the Tekran instrument needs days rather than hours to stabilise within a $1 \%$ margin required for precision measurements (Barratt, 1981). We thus conclude that the limited time of the cruises and the field conditions onboard ships are at least partly responsible for the large spread of the data from shipborne measurements.

We also report here an increasing trend for mercury concentrations at Cape Point for the period 2007-2013. No significant trend could be detected in mercury concentrations measured at Troll research station in Antarctica over the same period, but this is at least partly due to pronounced seasonal variations at Troll. As mercury concentrations at Cape Point decreased over the period 1996-2004, we conclude that the trend must thus have changed in direction between 2004 and 2007. Such change is qualitatively consistent with the trend changes observed at Mace Head in the Northern Hemisphere (Weigelt et al., 2014).

Acknowledgements. This work contributes to European Community FP7 project Global Mercury Observation System (GMOS). For Amsterdam Island, logistical support and financial support were provided by French Polar Institute IPEV (program 1028, GMOStral). Financial support was also provided by a grant from Labex OSUG@2020 (ANR10 LABX56) and LEFE CNRS/INSU (program SAMOA). We deeply thank the overwintering staff: B. Bouillard, J. Chastain, E. Coz, A. Croguennoc, M. Le Dréau, and V. Lucaire. Aurélien Dommergue acknowledges the Institut Universitaire de France. The Australian Bureau of Meteorology in Australia and CSIRO are also thanked for their continuous support of Cape Grim station. We also sincerely thank the staff at Cape Grim, S. Cleland, J. Ward, N. Sommerville and S. Baley. We acknowledge the support of the Cape Grim Science program student scholarship program. For Troll, financial support to sustain measurements is given through the Norwegian Antarctic Research Expeditions (NARE) programme administered by the Norwegian Polar Institute (NPI). We are very grateful for the technical support offered by the overwintering NPI staff at Troll. The NILU field team, but especially Jan H. Wasseng, is thanked for annual maintenance of the equipment at the Troll station.
The article processing charges for this open-access publication have been covered by the Max Planck Society.

Edited by: A. Dastoor

\section{References}

Aas, W. (Ed.): Data Quality 2004, Quality Assurance, and Field Comparisons, EMEP/CCC-Report 4/2006, NILU, Kjeller, Norway 2006.

Ambrose, J. L., Lyman, S. N., Huang, J., Gustin, M. S., and Jaffe, D. A.: Fast time resolution oxidized mercury measurements during the Reno Atmospheric Mercury Intercomparison Experiment (RAMIX), Environ. Sci. Technol. 47, 7285-7294, 2013.

Angot, H., Barret, M., Magand, O., Ramonet, M., and Dommergue, A.: A 2-year record of atmospheric mercury species at a background Southern Hemisphere station on Amsterdam Island, Atmos. Chem. Phys., 14, 11461-11473, doi:10.5194/acp14-11461-2014, 2014.

Barratt, R. S.: The preparation of standard gas mixtures, Analyst, 106, 817-849, 1981.

Brown, R. J. C., Brown, A. S., Yardley, R. E., Corns, W. T., and Stockwell, P. B.: A practical uncertainty budget for ambient mercury vapour measurement, Atmos. Environ. 42, 2504-2517, 2008.

Brunke, E.-G., Labuschagne, C., Parker, B., Scheel, H. E., and Whittlestone, S.: Baseline air mass selection at Cape Point, South Africa: Application of ${ }^{222} \mathrm{Rn}$ and other filter criteria to $\mathrm{CO}_{2}$, Atmos. Environ., 38, 5693-5702, 2004.

Brunke, E.-G., Ebinghaus, R., Kock, H. H., Labuschagne, C., and Slemr, F.: Emissions of mercury in southern Africa derived from long-term observations at Cape Point, South Africa, Atmos. Chem. Phys., 12, 7465-7474, doi:10.5194/acp-12-74652012, 2012.

Ebinghaus, R., Jennings, S. G., Schroeder, W. H., Berg, T., Donaghy, T., Guentzel, J., Kenny, C., Kock, H. H., Kvietkus, K., Landing, W., Mühleck, T., Munthe, J., Prestbo, E. M., Schneeberger, D., Slemr, F., Sommar, J., Urba, A., Wallschläger, D., and Xiao, Z.: International field intercomparison measurements of atmospheric mercury species, Atmos. Environ. 33, 3063-3073, 1999.

Ebinghaus, R., Jennings, S. G., Kock, H. H., Derwent, R. G., Manning, A. J., and Spain, T. G.: Decreasing trend in total gaseous mercury observations in baseline air at Mace Head, Ireland, from 1996 to 2009, Atmos. Environ., 45, 3475-3480, 2011.

Ebinghaus, R., Slemr, F., Brenninkmeijer, C. A. M., van Velthoven, P., Zahn, A., Hermann, M., O' Sullivan, D. A., and Oram, D. E.: Emission of gaseous mercury from biomass burning in South America in 2005 observed during CARIBIC flights, Geophys. Res. Lett. 34, L08813, doi:10.1029/2006GL028866, 2007.

Gustin, M. S., Huang, J., Miller, M. B., Peterson, C., Jaffe, D. A., Ambrose, J., Finley, B. D., Lyman, S. N., Call, K., Talbot, R., Feddersen, D., Mao, H., and Lindberg, S. E.: Do we understand what the mercury speciation instruments are actually measuring? Results of RAMIX, Environ. Sci. Technol. 47, 7295-7306, 2013.

Hansen, G., Aspmo, K., Berg, T., Edvardsen, K., Fiebig, M., Kallenborn, R., Krognes, T., Lunder, C., Stebel, K., Schmidbauer, N., 
Solberg, S., Espen Yttri, K.: Atmospheric monitoring at the Norwegian Antarctic station Troll: measurement programme and first results, Polar. Res., 28, 353-363, 2009.

Huang, J., Miller, M. B., Weiss-Penzias, P., and Gustin, M. S.: Comparison of gaseous oxidized $\mathrm{Hg}$ measured by $\mathrm{KCl}$-coated denuders, and nylon and cation exchange membranes, Environ. Sci. Technol., 47, 7307-7316, 2013.

Kaiser, R. and Gottschalk, G.: Elementare Tests zur Beurteilung von Meßdaten, Bibliographisches Institut, Mannheim, 1972.

Kuss, J., Zülicke, C., Pohl, C., and Schneider, B.: Atlantic mercury emission determined from continuous analysis of the elemental mercury sea-air concentration difference within transects between $50^{\circ} \mathrm{N}$ and $50^{\circ} \mathrm{S}$, Global Biogeochem. Cy., 25, GB3021, doi:10.1029/2010GB003998, 2011.

Landis, M. S., Stevens, R. K., Schaedlich, F., and Prestbo, E. M.: Development and characterization of an annular denuder methodology for the measurement of divalent inorganic reactive mercury in ambient air, Environ. Sci. Technol. 36, 3000-3009, 2002.

Müller, D., Wip, D., Warneke, T., Holmes, C. D., Dastoor, A., and Notholt, J.: Sources of atmospheric mercury in the tropics: continuous observations at a coastal site in Suriname, Atmos. Chem. Phys., 12, 7391-7397, doi:10.5194/acp-12-7391-2012, 2012.

Muntean, M., Janssens-Maenhout, G., Song, S., Selin, N. E., Olivier, J. G. J., Guizzardi, D., Maas, R., and Dentener, F.: Trend analysis from 1970 to 2008 and model evaluation of EDGARv4 global gridded anthropogenic mercury emissions, Sci. Tot. Environ., 494-495, 337-350, 2014.

Munthe, J., Wängberg, I., Pirrone, N., Iverfeldt, A., Ferrara, R., Ebinghaus, R., Feng, X., Gardfeldt, K., Keeler, G., Lanzillotta, E., Lindberg, S. E., Lu, J., Mamane, Y., Prestbo, E., Schmolke, S., Schroeder, W. H., Sommar, J., Sprovieri, F., Stevens, R. K., Stratton, W., Tuncel, G., and Urba, A.: Intercomparison of methods for sampling and analysis of atmospheric mercury species, Atmos. Environ. 35, 3007-3017, 2001.

Pfaffhuber, K. A., Berg, T., Hirdman, D., and Stohl, A.: Atmospheric mercury observations from Antarctica: seasonal variation and source and sink region calculations, Atmos. Chem. Phys., 12, 3241-3251, doi:10.5194/acp-12-3241-2012, 2012.

Salmi, T., Määttä, A., Anttila, P., Ruoho-Airola, T., and Amnell, T.: Detecting trends of annual values of atmospheric pollutants by the Mann-Kendall test and Sen's slope estimates - the Excel template application Makesens, Finnish Meteorological Institute, Helsinki, Finland, 2002.

Slemr, F., Schuster, G., and Seiler, W.: Distribution, speciation, and budget of atmospheric mercury, J. Atmos. Chem. 3, 407-434, 1985.

Slemr, F., Brunke, E.-G., Labuschagne, C., and Ebinghaus, R.: Total gaseous mercury concentrations at the Cape Point GAW station and their seasonality, Geophys. Res. Lett. 35, L11807, doi:10.1029/2008GL033741, 2008.
Slemr, F., Brunke, E.-G., Ebinghaus, R., and Kuss, J.: Worldwide trend of atmospheric mercury since 1995, Atmos. Chem. Phys. 11, 4779-4787, doi:10.5194/acp-11-4779-2011, 2011.

Slemr, F., Brunke, E.-G., Whittlestone, S., Zahorowski, W., Ebinghaus, R., Kock, H. H., and Labuschagne, C.: ${ }^{222}$ Rn-calibrated mercury fluxes from terrestrial surface of southern Africa, Atmos. Chem. Phys., 13, 6421-6428, doi:10.5194/acp-13-64212013, 2013.

Soerensen, A. L., Skov, H., Jacob, D. J., Soerensen, B. T., and Johnson, M. S.: Global concentrations of gaseous elemental mercury and reactive gaseous mercury in the marine boundary layer, Environ. Sci. Technol. 44, 7425-7430, 2010.

Soerensen, A. L., Jacob, D. J., Streets, D. G., Witt, M. L. I., Ebinghaus, R., Mason, R. P., Andersson, M., and Sunderland, E. M.: Multi-decadal decline of mercury in the North-Atlantic atmosphere explained by changing subsurface seawater concentrations, Geophys. Res. Lett. 39, L21810, doi:10.1029/2012GL053736, 2012.

Steffen, A. and Schroeder, W.: Standard operation procedures manual for total gaseous mercury measurements, Canadian Mercury Measurement Network (CAMNet), Version 4.0, March 1999.

Steffen, A., Scherz, T., Olson, M., Gay, D., and Blanchard, P.: A comparison of data quality control protocols for atmospheric mercury speciation measurements, J. Environ. Monitor., 14, 752$765,2012$.

Streets, D. G., Zhang, Q., and Wu, Y.: Projections of global mercury emissions in 2050, Environ. Sci. Technol. 43, 2983-2988, 2009.

Temme, C., Einax, J. W., Ebinghaus, R., and Schroeder, W. H.: Measurements of atmospheric mercury species at a coastal site in the Antarctic and over the South Atlantic Ocean during polar summer, Environ. Sci. Technol. 37, 22-31, 2003.

Wang, F., Saiz-Lopez, A., Mahajan, A. S., Gómez Martín, J. C., Armstrong, D., Lemes, M., Hay, T., and Prados-Roman, C.: Enhanced production of oxidised mercury over the tropical Pacific Ocean: a key missing oxidation pathway, Atmos. Chem. Phys., 14, 1323-1335, doi:10.5194/acp-14-1323-2014, 2014.

Weigelt, A., Ebinghaus, R., Manning, A. J., Derwent, R. G., Simmonds, P. G., Spain, T. G., Jennings, S. G., and Slemr, F.: Analysis and interpretation of 18 years of mercury observations since 1996 at Mace Head at the Atlantic Ocean coast of Ireland, Atmos. Environ. 100, 85-93, 2015.

Widmer, A. E., Fehlmann, R., and Rehwald, W.: A calibration system for calorimetric mass flow devices, J. Phys. E: Sci. Instrum., $15,213-220,1982$

Xia, C., Xie, Z., and Sun, L.: Atmospheric mercury in the marine boundary layer along a cruise path from Shanghai, China, to Prydz Bay, Antarctica, Atmos. Environ., 44, 1815-1821, 2010. 